\title{
STUDENT PROJECT: A SURVEY OF BRYOPHYTES AND THEIR MANAGEMENT IN THE FERNS AND FOSSILS HOUSE AT THE ROYAL BOTANIC GARDEN EDINBURGH
}

\author{
Hazel France ${ }^{l}$
}

\begin{abstract}
This paper is derived from a research project produced during the author's studies for a BSc in Horticulture with Plantsmanship at the Royal Botanic Garden Edinburgh (RBGE). The body of work represents findings from a floristic survey of naturally occurring bryophytes in the Ferns and Fossils House at RBGE. This site merited close study due to the known presence of at least two southern hemisphere species along with many native species. Horticultural staff were interviewed about current bryophyte management within glasshouse displays. Recommendations are made for raising the status of bryophytes in botanic gardens and expanding the scope of living collections. This report includes an introduction, literature review, methodology, survey results, interview summary and conclusion.
\end{abstract}

\section{INTRODUCTION}

Bryophytes are an important area of research at the Royal Botanic Garden Edinburgh (RBGE). In addition, the UK has a richly diverse native bryophyte flora. However, this is not currently reflected in the living collections, and bryophytes are under-represented in botanic garden collections in general. However, naturalistic glasshouse displays such as those at RBGE have abundant, naturally occurring populations of mosses and liverworts, and these are an unintentional yet key component of displays.

In this project, a floristic survey of the naturally occurring bryophyte flora in the Ferns and Fossils House at RBGE was conducted. This glasshouse was selected for study as populations of two southern hemisphere species had been previously identified within the fern house, most likely introduced as 'hitch-hikers' on tree ferns in the late 1800s. Compiling a species list of the current bryophyte flora had the potential to highlight the presence of further exotic species, along with many natives.

A total of 30 species were recorded. Of these, 21 were native, 4 were of southern hemisphere origin and 5 did not match descriptions of any common British taxa and are potentially exotic species.

Horticultural staff responsible for the fern, arid and carnivorous plant displays were interviewed about bryophyte management within these areas. Some mosses provide a valuable microhabitat for epiphytes, whilst vigorous moss and liverwort species

1. Hazel France was a student on the BSc in Horticulture with Plantsmanship course at the Royal Botanic Garden Edinburgh from 2015 to 2018.

Address: 20A Inverleith Row, Edinburgh EH3 5LR, UK.

Email: hfrance@rbge.org.uk 
can become major weeds. The Arid Lands collection contains the only wild-collected bryophytes in the living collection.

Bryophytes are arguably an aesthetically and ecologically important element of glasshouse displays. Recommendations for incorporation of bryophytes into the living collection include accessioning and labelling significant stable populations. Bryophytes are not referred to in the RBGE Acquisitions Policy (Rae et al., 2006). To include these would allow the cultivation potential of rare, interesting and spectacular wild-collected bryophytes to be explored. This would expand the scope of the living collection, utilise the bryological expertise within the Science Division of RBGE, and highlight the significance and diversity of this fascinating group of plants. Developing methodologies for the cultivation of bryophytes is potentially vital for their ex situ conservation and research in the future.

\section{LITERATURE REVIEW}

\section{Bryophyte biodiversity}

Bryophytes comprise three groups of land plants: mosses, liverworts and hornworts. Although they exhibit many similar morphological and physiological characteristics, they may not comprise a monophyletic lineage (Goffinet \& Shaw, 2009) and the phylogeny of bryophytes is still not fully understood (Simpson, 2010). As the closest extant relatives of the first land plants, bryophytes are thought to have provided a pivotal step in the evolution of vascular plants over 400 million years ago (Vanderpoorten \& Goffinet, 2009).

Unlike higher plants, bryophytes lack complex vascular systems for water transport and structural support, which limits their size. Bryophytes also differ from other land plants in that the dominant part of the life cycle - the persistent photosynthesising 'plant' - is the gametophyte (Simpson, 2010). Borne on the gametophyte, the sporecontaining sporophyte is temporary and dependent on the gametophyte for water and nutrient transfer. Bryophytes require water for sexual reproduction, to allow flagellate sperm to swim from the male antheridia to the female archegonia (Evert et al., 2013). Thus, they are often associated with wet habitats, although many can undergo extreme desiccation, enabling them to survive periods of drought. In an extreme example, shoots of the commonly occurring moss Syntrichia ruralis were found to regenerate upon hydration after being stored as a dry herbarium specimen for 20 years (Stark et al., 2016).

Mosses (Bryophyta) are a group of around 13,000 species globally (Goffinet \& Shaw, 2009). Moss leaves are usually spirally arranged around the stem and can have midrib-like structures called costae which provide structural support. Mosses are split into two main groups: acrocarps and pleurocarps. Acrocarp mosses have upright stems with the sporophyte and archegonia borne at the shoot tips. This structure means that colonies can appear as dense, rounded cushions. Pleurocarp mosses have more 
complex branched structures and can therefore form mats by spreading horizontally, each plant producing multiple sporophytes along the main stem (Atherton et al., 2010).

The sporophytes of most mosses consist of a seta and capsule, with peristome teeth controlling spore dispersal. Capsules can remain on the plant after spores have been dispersed and are often important for identification.

Liverworts (Marchantiophyta) have an estimated 5,200 species worldwide (Evert et al., 2013). This group is further split into complex thallose, simple thallose and leafy liverworts. Thallose liverworts are flattened mats of tissue, often with dichotomous branching patterns and simple rhizoids for anchorage, moisture and nutrient absorption (Simpson, 2010).

Leafy liverworts account for 80 per cent of liverwort diversity (Vanderpoorten \& Goffinet, 2009) and their stem and leaf morphology means that they can superficially resemble mosses. However, liverwort leaves are always only one layer of cells thick, lack costae and are arranged in two or three parallel rows along the stem (Vanderpoorten \& Goffinet, 2009). When present, this third rank usually comprises smaller underleaves on the ventral side of shoots, giving plants an overall flattened appearance (Goffinet \& Shaw, 2009). Unlike the mostly simple leaves of mosses, liverwort leaf morphology is diverse, with modifications such as divided leaves and prominent or inflated lobes (Vanderpoorten \& Goffinet, 2009).

Although they differ remarkably in overall morphology, simple thalloid and leafy liverworts share similar sporophyte structures. The sporangium is held within a round capsule and an epidermis lacking stomata (Vanderpoorten \& Goffinet, 2009). Upon maturation, the seta quickly elongates and the capsule opens along four vertical slits to release spores (Goffinet \& Shaw, 2009). The seta is translucent and is short lived, disintegrating after spore release (Simpson, 2010).

Hornworts (Anthocerotophyta) are a group of just 300 species (Evert et al., 2013). Superficially resembling thalloid liverworts, they are differentiated by their sporophytes, which are cylindrical capsules that split vertically down their full length to release spores. Hornwort sporophytes are produced from a basal meristem which enables spores to be continually produced and released throughout the life of the sporophyte structure, unlike mosses and liverworts (Vanderpoorten \& Goffinet, 2009).

\section{Bryophyte distribution}

Bryophytes have a large natural dispersal range due to the small size and therefore high mobility of spores in air currents. This distribution is often restricted to a species' native hemisphere, as the intertropical convergence zone acts as a barrier. Import of bryophytes as plants, spores, tubers or gemmae on ornamental plants or in contaminated compost is a major pathway for bryophyte introduction across the equator (Essl et al., 2013). Once this barrier has been crossed, local environmental constraints limit colonisation. Spore longevity varies greatly between species (Vanderpoorten \& Goffinet, 2009). 
The diverse topography and geology of the UK, coupled with a mild, wet oceanic climate, provide ideal climatic conditions for bryophytes. The British Isles are home to 1,048 native species: 752 mosses, 292 liverworts and 4 hornworts (Villarreal et al., 2014). This is around two-thirds of all European species, whereas only a sixth of Europe's angiosperm and fern flora are represented in the UK (Atherton et al., 2010). The UK is therefore important in the study of bryophytes.

With 22 introduced species, the UK has the highest reported number of alien bryophytes in Europe (Essl et al., 2013). However, the diverse native bryophyte flora outcompetes introduced species in most natural ecosystems. Alien species can gain a foothold in modified habitats or those with little vegetation (Essl et al., 2013).

\section{Bryophytes in horticulture}

\section{Japanese gardens}

Generally considered to be of little ornamental value in western horticulture, bryophytes have a history of use in Japanese gardens. They are valued for their small size, and carpets of moss are used in conjunction with rocks and ponds to create the feeling of tranquil, miniaturised landscapes. In Japanese gardens, the evergreen nature of bryophytes symbolises long life, in contrast to the showy displays of ephemeral flowers prized in western horticulture (Glime, 2008).

In the Kyoto area, year-round high humidity and a long summer rainy season provide an ideal climate for bryophyte cultivation. The region is famous for its temple moss gardens, of which Saiho-ji is one of the most renowned (Martin, 2015). First established in the 8th century, Saiho-ji was not originally designed as a moss garden, but the bryophyte flora took over during a long period of neglect. Instead of then eradicating the mosses, this natural biodiversity was embraced and became a deliberate feature from the mid-19th to early 20th century (Martin, 2015). With continued maintenance to optimise their growing conditions, mosses now thrive within the garden and 120 species have been recorded to date (Martin, 2015). Communities are actively managed with undesirable species weeded out and naturally occurring species supplemented with others transplanted from the surrounding mountains (Iwatsuke \& Kodama, 1961).

The temple garden at Gingkaku-ji (the Silver Temple), also in Kyoto, includes an educational display of bryophytes within the garden. Potted mosses and liverworts are displayed with their Japanese names and information on their significance and use. Species considered weedy or unappealing are classed as 'interrupter' species as they interrupt the tranquillity of the garden (Glime, 2008). Interrupter species include thallose liverworts Conocephalum conicum and Marchantia polymorpha (Itwatsuke \& Kodama, 1961).

\section{Scottish botanic gardens}

In reference to lichens, bryophytes and fungi, the RBGE Acquisitions Policy (Collection Policy, Appendix V) states: “These are important research groups for RBGE but they 
have never been included in any Acquisition Policy and none are deliberately cultivated" (Rae et al., 2006).

The document goes on to explain that as important groups for research and education, areas should be set aside for their natural growth to be encouraged, making use of microclimates, topography and tree canopy manipulation. There are examples of this throughout the four Gardens of RBGE.

Dawyck Botanic Garden near Peebles contains the world's first Cryptogamic Sanctuary garden in which bryophytes, lichens and fungi are encouraged. Constructed in 1992, wild-collected native trees and herbaceous woodland perennials are planted and moss-covered rocks, logs and tree stumps installed. Leaf mould, tree branches and stumps are left in situ to encourage fungal activity and colonisation by bryophytes and lichens (Watling, 2007). A Pinus sylvestris (Scots pine) that was blown down in high winds in 1993 has been left to decay naturally to diversify the habitats available for colonisation by flora and fauna (Fig. 1). Whilst bryophytes are not labelled, an interpretation panel includes images, common names and botanical names for the most abundant species. The Dawyck Garden as a whole is rich in bryophytes. A survey in 2015 recorded 114 species, one of which has only been recorded in Scotland four times since 1950.

The Cryptogamic Garden at the Edinburgh Garden is a native woodland garden where cryptogams are encouraged. Tree branches and stumps have been added for bryophyte and lichen colonisation, but few are present. On the woodland floor, bryophytes are outcompeted by vascular plants.

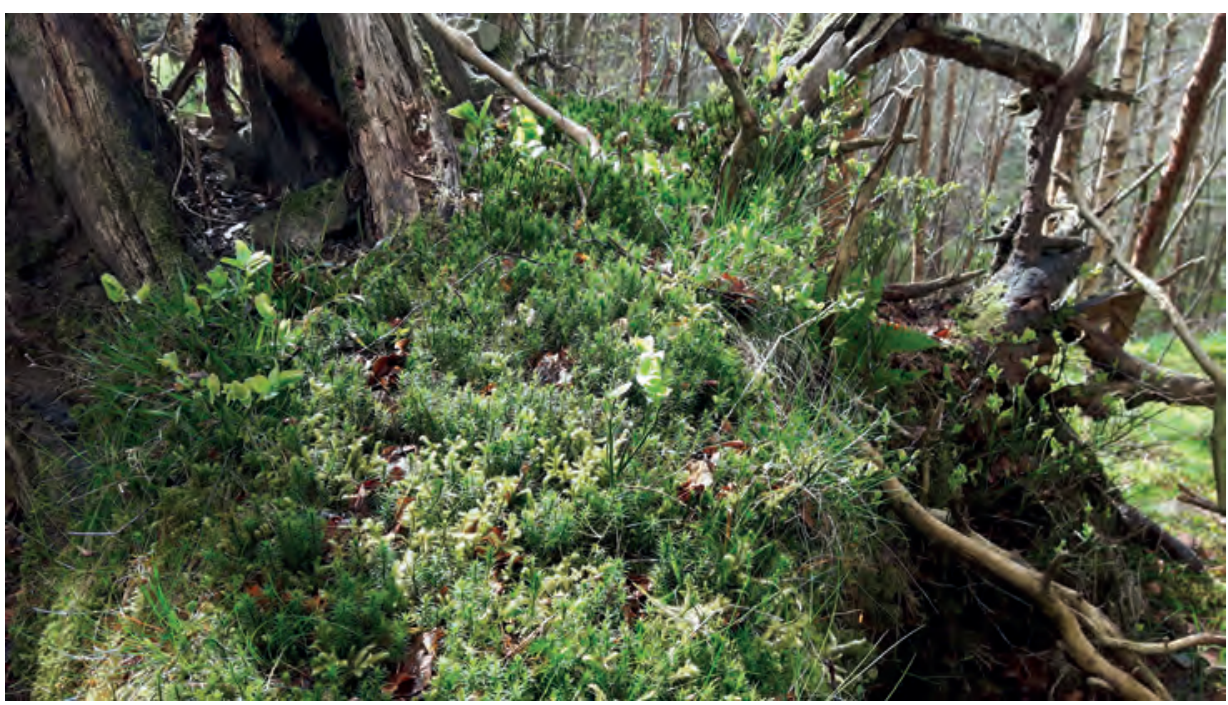

Fig. 1 Wind-blown Pinus sylvestris (Scots pine) at Dawyck Cryptogamic Sanctuary. It is colonised by local flora, including many bryophytes. Photo: H. France. 
A species list of the bryophyte flora of the outdoor areas at the Edinburgh Garden was compiled by Elizabeth Kungu, Research Associate, in 2016. This list includes 76 mosses, 20 liverworts and 1 hornwort species. None of these is currently labelled.

At Glasgow Botanic Gardens, the abundantly growing thalloid liverwort Conocephalum conicum is labelled in the tropical fern house. The label deviates from the standard format used for all accessioned plants and states simply: LIVERWORT, Conocephalum conicum (L.) Lindb. (Fig. 2). This plant is not part of the living collection, but the label provides basic information for the public as it is an abundant and visually striking part of the display.

\section{PROJECT AIMS}

This project aims to record the current bryophyte biodiversity in the Ferns and Fossils Glasshouse at RBGE and explore avenues for their inclusion in botanic garden horticulture, thereby broadening the scope of the living collection.

\section{PRIMARY RESEARCH METHODS}

\section{Survey methodology}

The primary site of investigation was the Ferns and Fossils House at RBGE (Fig. 3). This house is open to the public and displays many southern hemisphere ferns and conifers. Hard landscaping features include paths, stone walls bordering raised beds, a stream and a small pond. Beds are top-dressed with fine-grade chipped bark.

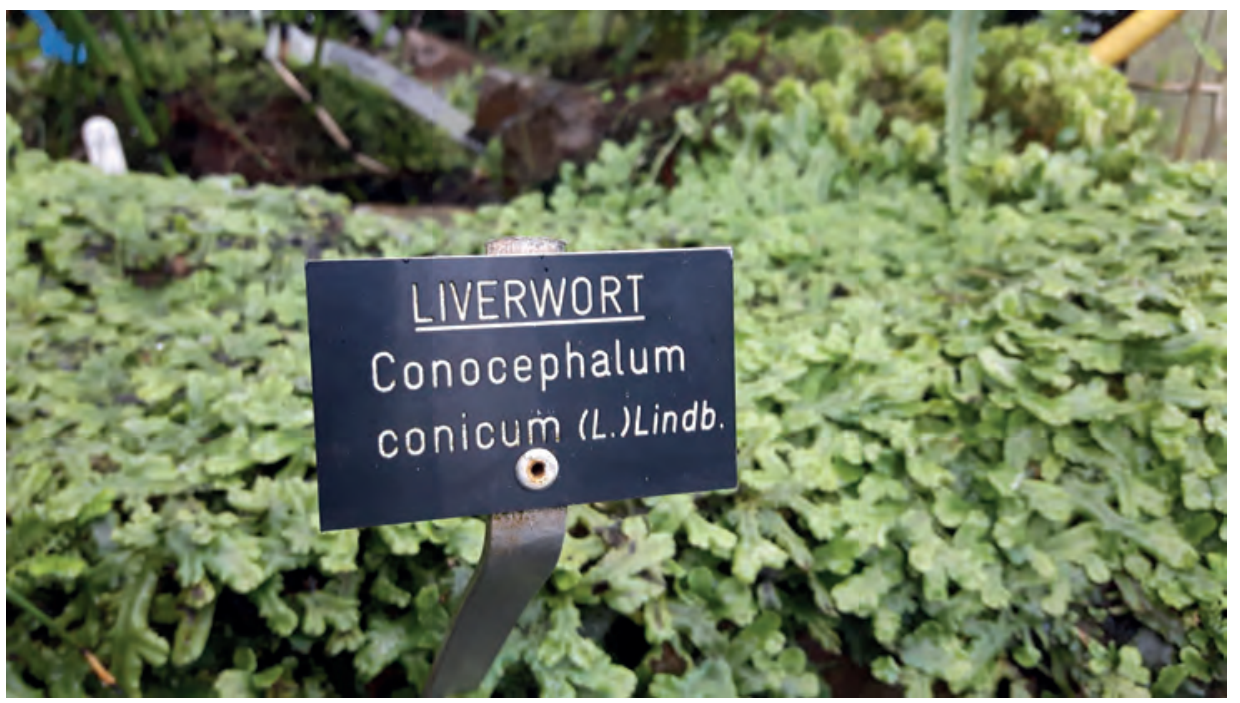

Fig. 2 Thallose liverwort Conocephalum conicum labelled in the tropical fern house at Glasgow Botanic Gardens. Photo: H. France. 


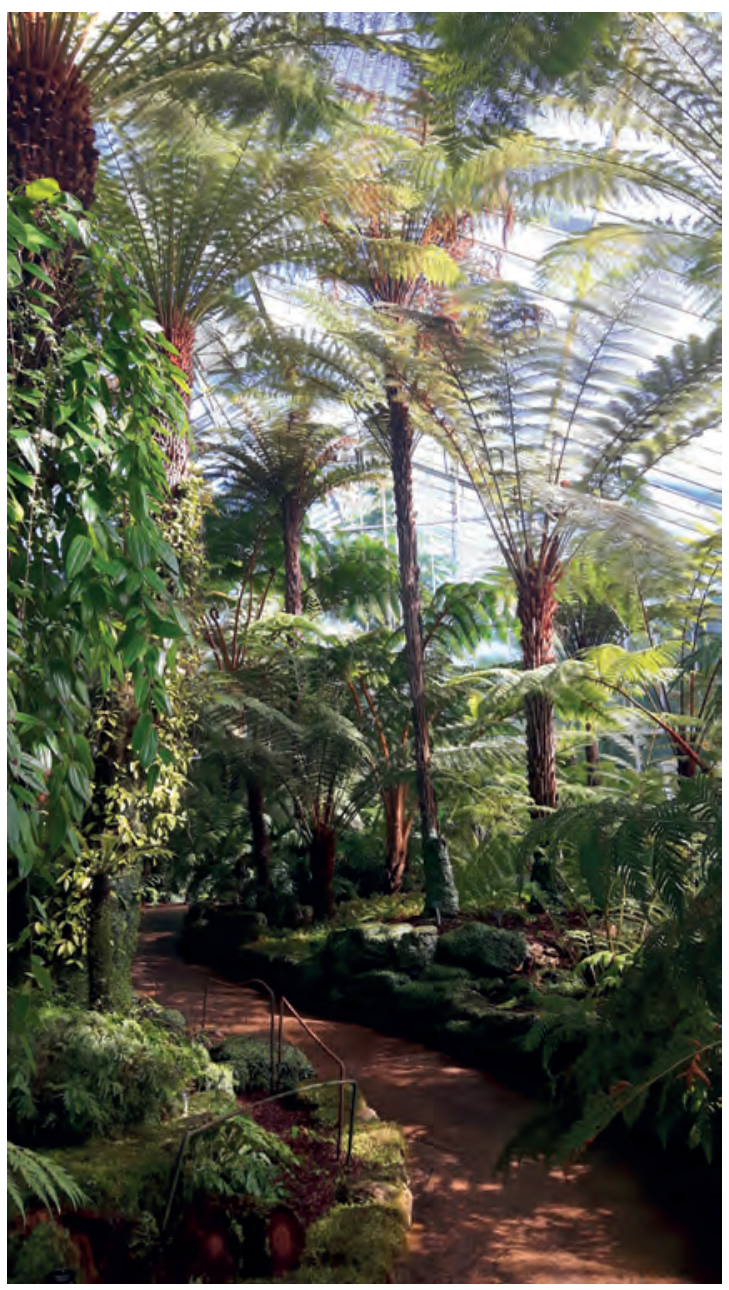

Fig. 3 Ferns and Fossils House display of southern hemisphere ferns and conifers. Naturally occurring bryophytes are abundant on rocks and tree fern trunks. Photo: H. France.

An initial walk-round of the Fern House was conducted with RBGE bryologists Neil Bell, Elizabeth Kungu and David Chamberlain on 27 October 2016. Species of interest were highlighted, confirming the presence of southern hemisphere taxa and the need for a full species list of the bryophytes in the glasshouses.

\section{Collection methods}

Bryophyte collections were made between January and May 2017. As the aim of this survey was to compile a comprehensive inventory of the species diversity in the Fern House, it was essential that all areas were examined methodically. From the door, collections were made in an anti-clockwise direction around the perimeter beds, then around the outside and then the inside of the central beds. A hand lens was used to differentiate 
between species, and multiple samples were collected of each. Small samples were collected to minimise impact on potentially small populations and avoid disturbing the display. Plants bearing sporophytes were collected where possible. Samples were removed from surfaces using tweezers or a knife (Fig. 4) and each was placed in a separate envelope with the following data recorded on the outside:

1. Collection number

2. Date of collection

3. Description of location

4. Bed number

5. Growing substrate: rock, ground (chipped bark), path, fern trunk, fern crown

6. Aspect

7. Exposure (full sun, partial shade, shade, deep shade)

After identification, the abundance of all species was recorded in the following categories: very infrequent, infrequent, frequent, abundant, highly abundant.

\section{Identification methods}

Preliminary identification attempts were made using Mosses and Liverworts of Britain and Ireland: A Field Guide (Atherton et al., 2010). Dichotomous keys use simple language and illustrations are included to explain basic terminology. Specimens were examined using a $\times 30$ dissection microscope (Fig. 5) and dissection kit. Specimens

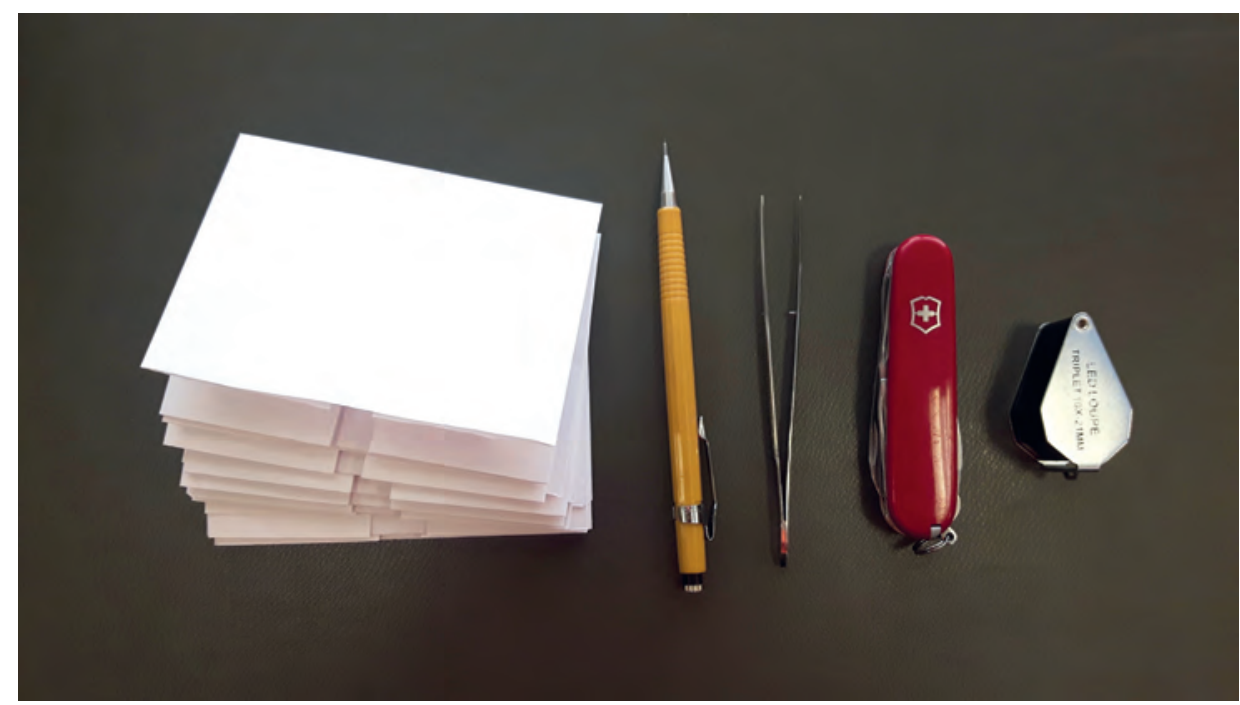

Fig. 4 Bryophyte collecting kit: paper envelopes, pencil, tweezers, pocket knife and hand lens. Photo: $\mathrm{H}$. France. 


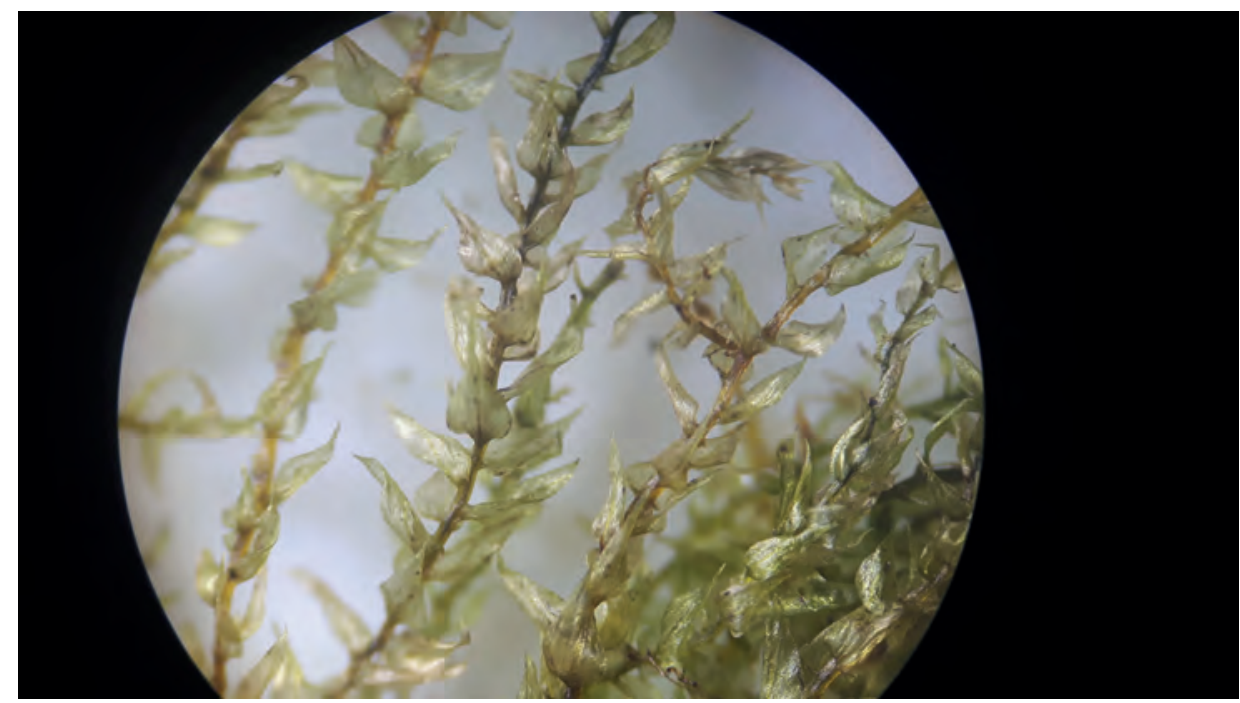

Fig. 5 View of Oxyrrhynchium hians through $\times 30$ binocular dissection microscope. Photo: H. France.

were examined wet and dry, as different key taxonomic characters can be displayed in each state.

Sketches were made of bryophytes during identification to aid observation of diagnostic characters. Comparison between samples of the same and different taxa was also useful for elucidating subtle differences between species. Where the field guide did not lead to successful identification, comprehensive moss and liverwort floras were used. Neil Bell and Elizabeth Kungu also provided essential identification and verification. All collection data and plant names were recorded in Microsoft Excel.

\section{Interviews}

Interviews were conducted with RBGE horticultural staff between November 2016 and May 2017. Bryophyte management issues were discussed.

\section{RESULTS}

\section{Survey results}

Thirty species were recorded in this survey of the RBGE Fern House. Twenty-one were common native species and four were southern hemisphere exotic species. Five did not match descriptions of any common British taxa and are potentially exotic species. Eighteen of the thirty species found had not been previously recorded in outdoor areas of RBGE.

Rocks were the most species-rich substrate within the glasshouse. The most abundant species was thalloid liverwort Conocephalum conicum. The least abundant 
species was a southern hemisphere moss, Achrophyllum dentatum, of which only one sample was found.

See Appendix I for full results of the survey.

\section{Interview results}

As a result of interviews with horticultural staff, it was agreed that there was scope for incorporating bryophytes into the living collection, and that this could include labelling with 'Moss' or 'Liverwort' for clarity. Wild-collected bryophytes could be brought into the public displays if they provided visitor interest.

The Arid Lands collection contains seven collections of thallose liverwort Plagiochasma spp., the only wild-collected bryophytes currently cultivated at RBGE (Figs 6 \& 7). Gunnar $\emptyset$ vsteb $\varnothing$, who manages the Arid Lands collection, suggests that bryophytes are a natural addition to the collection because many lithophytic species are more tolerant of desiccation than desert-dwelling angiosperms.

The few attempts at cultivating wild-collected mosses have been less successful than with thalloid liverworts. For example, Dawsonia superba was collected in West Papua in 2009 but did not survive the quarantine process. However, there is potential

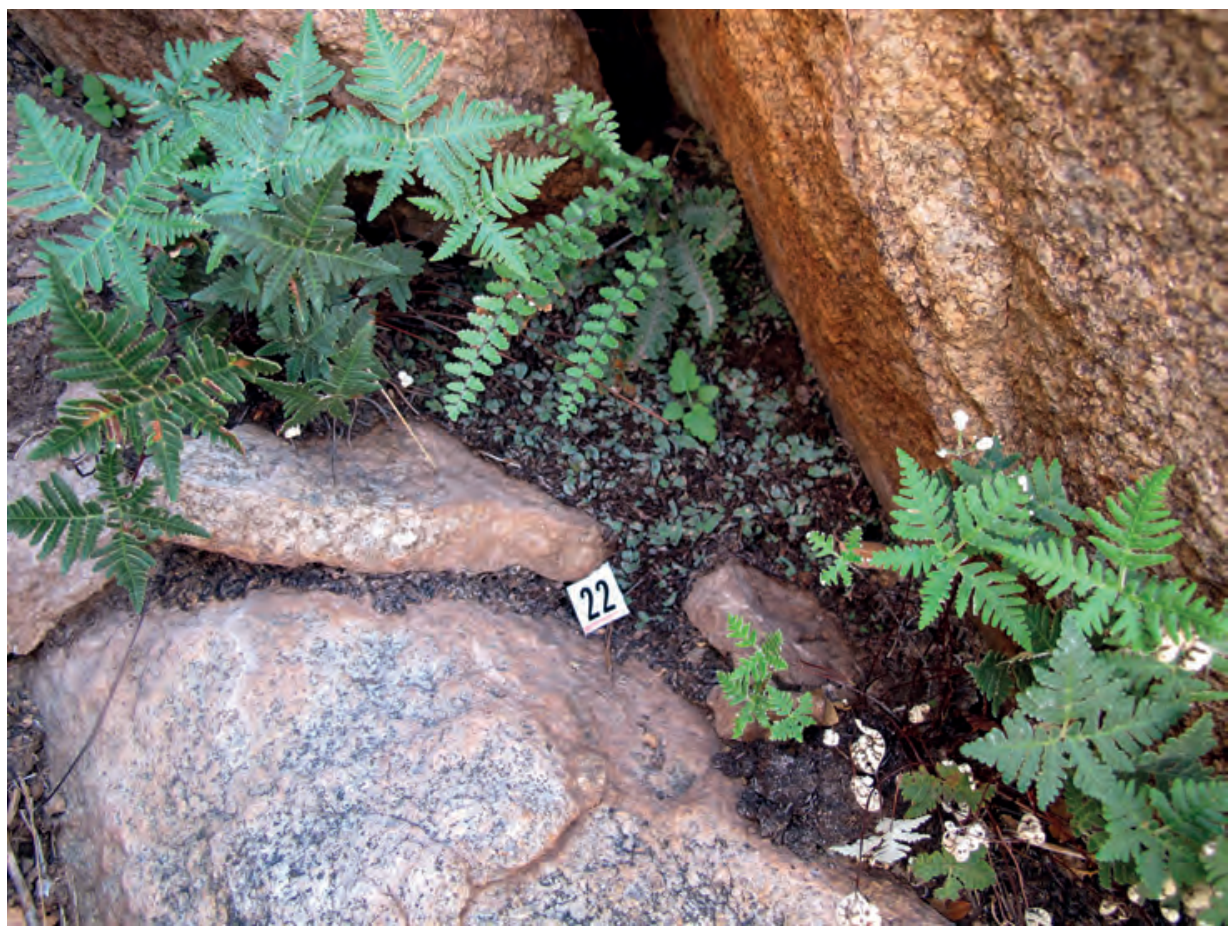

Fig. 6 Liverwort Plagiochasma cuneatum in west Texas. It is growing with xerophytic ferns in a crevice between rocks. Photo: (C) A. Ensoll (2011). 


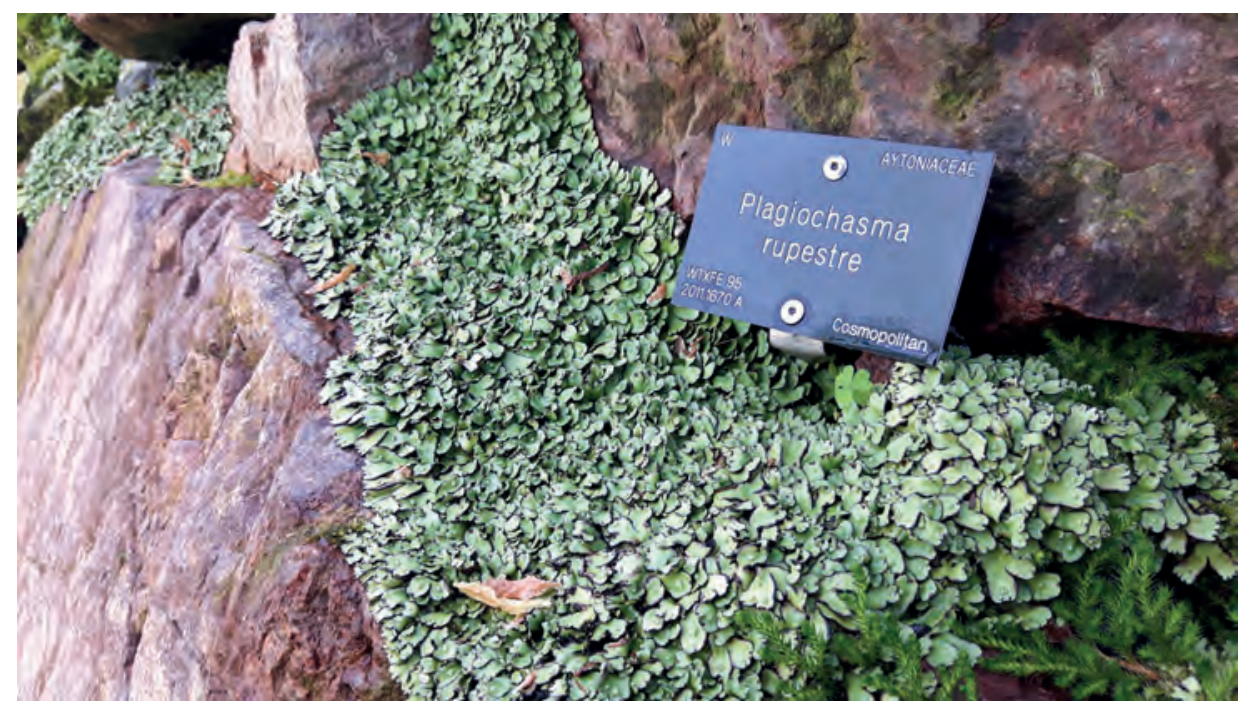

Fig. 7 Wild-collected liverwort Plagiochasma rupestre in the Arid Lands Glasshouse at RBGE. Photo: H. France.

for cultivating mosses due to their dessication tolerance and ability to regenerate from small fragments. This is an area for future experimentation, building upon the success of liverwort cultivation.

See Appendix II for an extended summary of the interview results.

\section{DISCUSSION}

Southern hemisphere hitch-hikers

All four exotic bryophyte species found in the Fern House have been found elsewhere in British botanic gardens.

Hypopterygium tamarisci is a relatively large dendroid moss with a pantropical and warm-temperate distribution (Kruijer, 2002). Throughout its Australasian range, H. tamarisci is frequently found on tree ferns and can propagate from spores, gemmae, fragments of branches or detached leaves (Kruijer, 2002). Molecular analyses conducted on Hypopterygium specimens from three botanic gardens in Scotland, Germany and Portugal confirmed that all populations were $H$. tamarisci from Australia or New Zealand, strongly suggesting that it arrived with tree ferns in the late 1800 s (Stech \& Pfeiffer, 2006).

Despite its southern hemisphere origins, Hypopterygium tamarisci was first described in 1928 from a population growing in the tree fern grove at Kibble Palace, Glasgow Botanic Gardens (Dixon, 1928; Stech \& Pfeiffer, 2006). This collection of Dicksonia antarctica was planted in 1881, with individual plants arriving as donations 
from a variety of sources, including the Royal Botanic Gardens, Kew and RBGE (Curtis, 2006). H. tamarisci is still growing in abundance in the Kibble Palace (Fig. 8). It is also present in the restored Victorian Fernery at RBGE's Benmore Garden (Neil Bell, pers. comm.).

Hypopterygium tamarisci is growing abundantly in large patches in the Fern House at RBGE. It is a distinctive, large and attractive moss, easily differentiated from other species even with the untrained eye. As it shares a habitat and distribution range with many of the ferns in the collection, installing labels to highlight its presence and significance within the display is justifiable.

Achrophyllum dentatum (Fig. 9) is another southern hemisphere moss with accounts of naturalised populations occurring in Europe in proximity to tree ferns. It was identified under the name Pterygophyllum dentatum at the Kibble Palace in 1928, at the same time as Hypopterygium tamarisci was described (Dixon, 1928). It has been found growing outdoors in Cornwall with introduced filmy ferns (Rumsey, 2001), and in glasshouses at the Royal Botanic Gardens, Kew (Neil Bell, pers. comm.). A. dentatum was identified as growing on tree fern trunks in the RBGE Fern House in 1992 (Rumsey, 2001) and in this survey a very small population was found growing in a crevice between rocks. It was also found growing in the Temperate Glasshouse at RBGE in a small 'cave' constructed from old tree fern trunks, built to provide a microhabitat for filmy ferns.

Achrophyllum dentatum is dioecious and sporophytes have not been seen on UK populations. Therefore, asexual reproduction by gemmae is the sole method of dispersal (Rumsey, 2001). These reproductive constraints, coupled with the evident requirements for constant high humidity, indicate that the cultivation and display potential for this

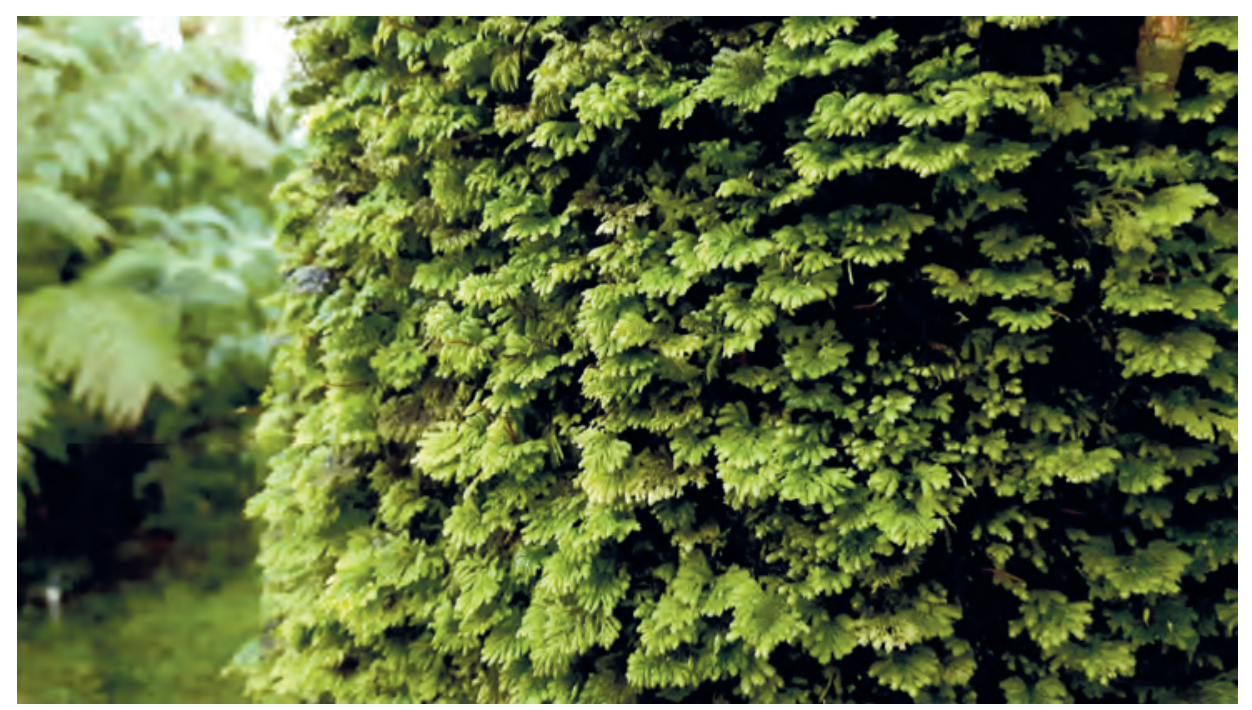

Fig. 8 Hypopterygium tamarisci on the trunk of Dicksonia antarctica in the Kibble Palace, Glasgow Botanic Gardens. Photo: H. France. 


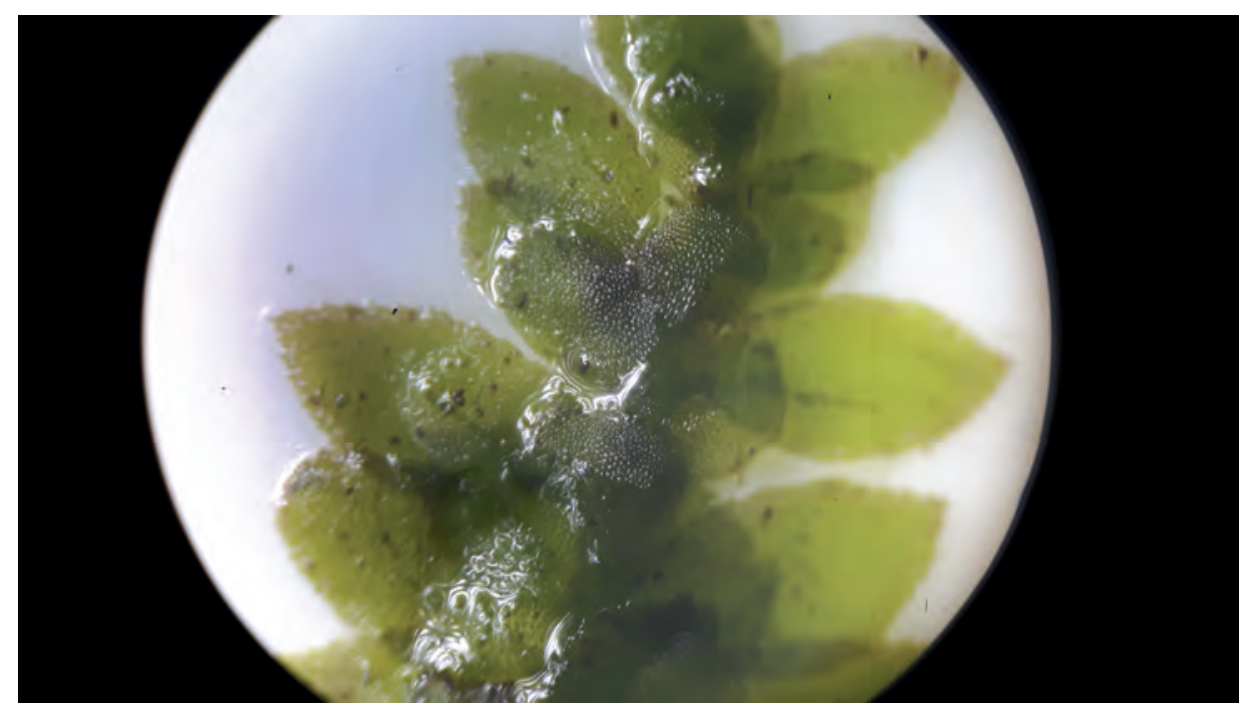

Fig. 9 View of Achrophyllum dentatum through $\times 30$ binocular dissection microscope. Photo: H. France.

species is extremely limited. However, it is an interesting hitch-hiker that has persisted since introduction in the late 1800s and therefore arguably worth accessioning and monitoring.

Leafy liverwort Tricholepidozia tetradactyla (Fig. 10) is another southern hemisphere species reported from a limited number of sites in the UK, all in proximity to botanic gardens. T. tetradactyla is locally abundant in the Fern House, particularly in the crowns of large ferns. Molecular analysis of the Fern House population in a earlier phylogenetic study indicated that the species was an introduction from New Zealand (Villarreal et al., 2014).

Vesicularia reticulata is a large, pleurocarpous moss found in abundance in the Fern House stream and pond on rocks and sediment. Native to Indonesia, the Philippines, Singapore and NW India, $V$. reticulata has previously been recorded in UK glasshouses and is a popular aquarium plant (Stevenson \& Jones, 1989).

\section{Recommendations for bryophyte management in the living collections}

\section{Fern House}

This study has found high bryophyte diversity in the Fern House at RBGE. Upon completion of the survey, accession numbers were created for the most abundant species and labels were ordered for these, as well as for species with previously existing accession numbers. As suggested by horticultural staff, the words 'Moss' or 'Liverwort' were included on the label instead of the family name. This will ensure that it is clear to the public what the labels are referring to and will help horticultural staff with stocktaking. A basic description of moss and liverwort species has also been added to the 
plant records database BGBase ${ }^{\mathrm{TM}}$ (Walter \& O'Neal, 1985-2018) for reference. Further bryophyte populations will be identified and labelled throughout the glasshouses in the future.

Even within botanic garden horticulture, bryophytes can be overlooked because of their small size and how challenging they can be to identify. The simple act of labelling populations of large and common species within the Garden could be a positive step in preventing this 'bryophyte blindness'. Labelling allows them to become more accessible to the public, and to be incorporated into horticultural and botanical education and training carried out at RBGE. This could ensure that future horticulturists are less intimidated by this challenging yet important aspect of biodiversity.

The next step to develop the management of bryophytes in the Fern House at RBGE would be to compile an illustrated list of the bryophyte flora for staff use. This would highlight the diversity and significance of species present and enable horticultural staff to make choices about what to keep, label or remove within displays. This would mirror the approach taken in managing Japanese moss gardens, where species are categorised into those of general importance, 'VIP' mosses and 'interrupter' species (Glime, 2008).

To increase the diversity of the bryophyte flora in the Fern House, additional substrates could be introduced. Just as the Pinus sylvestris was left for colonisation by flora and fauna in the Cryptogamic Sanctuary at Dawyck, old tree fern caudices could be added to the display. A greater variety of rock types and $\mathrm{pH}$ within displays could also increase diversity of lithophytic species (Lausen-Higgins, 2009).

The Fern House is a logical place to raise the profile of bryophytes as they are in keeping with theme of ancient, non-flowering plants that the display represents. Ferns and mosses are natural companions as early evolved, spore-bearing plants that require

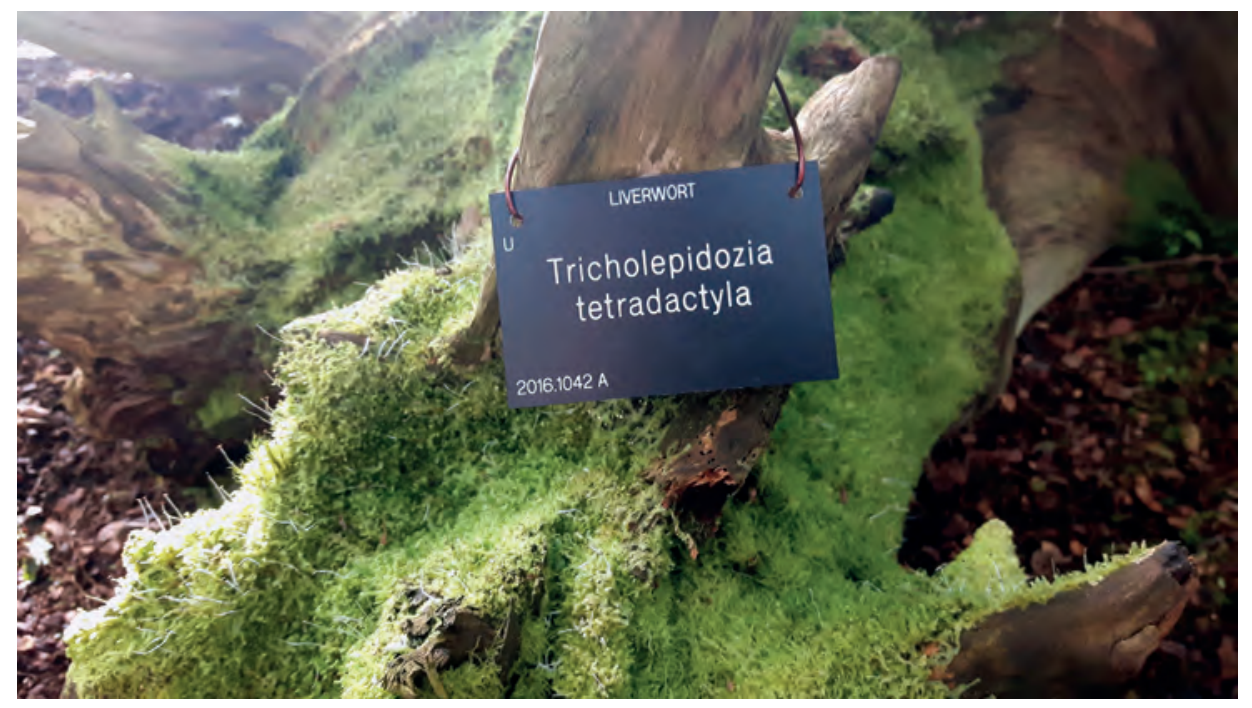

Fig. 10 Leafy liverwort, Tricholepidozia tetradactyla, with a label in the Fern House. Photo: H. France. 
high humidity and water to complete their life cycles. Bryophyte surveys could be conducted in other ferneries around the UK to compare communities, particularly the presence of exotic species. It is suggested that a bryophyte survey of the RBGE Fern House be repeated in future to monitor changes over time.

\section{Potential for bryophytes in glasshouse collections}

This survey revealed not only high diversity, but also that more than half of the species occurring are not present in outdoor areas of the Garden. Surveys could be repeated for all the glasshouses to compile a full catalogue of biodiversity. Other indoor collections, such as those in the Montane and Lowland Tropics Glasshouses, are expected to have much higher bryophyte diversity with more exotic species (David Chamberlain, pers. comm.). Within a relatively small area, glasshouse complexes such as those at RBGE represent a wide range of temperature and humidity regimes with many microhabitats. This has resulted in a wide range of ecological niches for bryophyte colonisation - both native and hitch-hiker species. Just as naturally occurring bryophyte biodiversity has been embraced in Japanese horticulture, the same approach could be taken in botanic garden glasshouses. Bryophytes are a valuable part of naturalistic displays that aim to mimic the habitats from which the plants originate. The RBGE glasshouses could become a hub for raising the profile of bryophytes, utilising and augmenting the naturally occurring flora.

Since completion of this survey, a number of bryophytes have been accessioned and labelled in the Arid Lands and carnivorous plant display case. A bryophyte trail through the glasshouses could be developed if more species were to be labelled in other areas.

\section{CONCLUSION}

All RBGE horticultural staff interviewed were enthusiastic and keen to learn more about the bryophtyes already growing within their glasshouses. Most of the ten public glasshouses at RBGE are designed as naturalistic displays, representative of various biomes from around the world. Naturalistic displays create an immersive visitor experience and broaden the range of ecological niches available for planting. Bryophytes are an important component of the ecosystems represented in the RBGE glasshouses. In glasshouse horticulture and in the wild, they provide useful microhabitats that can aid in the establishment and naturalisation of other plant species, particularly epiphytes and lithophytes. By surveying the current bryophyte populations, species of interest or use can be highlighted and methods developed for their management and deliberate cultivation. Developing this area of horticultural expertise would place botanic gardens in a better position for the cultivation of wild-collected bryophytes for display, research and conservation.

RBGE operates as part of a global network aiming to reach targets set out by the Global Strategy for Plant Conservation (GSPC). The Plant Diversity Challenge (Cheffings et al., 2004) outlines objectives for the UK to achieve these goals at a 
national level. RBGE is a major contributor to this effort, in part through ex situ conservation in the living collection. Key points from the Plant Diversity Challenge document are highlighted in the RBGE Collections Policy. They include 'Developing methodologies for the ex situ conservation and reintroduction of bryophytes' (Rae et al., 2006). Therefore, it is acknowledged that raising the profile of bryophytes within botanic gardens and developing cultivation protocols will enable bryophyte diversity to be conserved alongside that of vascular plants.

As a global network, botanic gardens currently hold more than 50 per cent of vascular plant genera in ex situ conservation, compared with less than 5 per cent of non-vascular plant genera (Mounce et al., 2017). Whilst the current RBGE Collections Policy states the importance of promoting naturally occurring bryophytes within designated areas (Rae et al., 2006), the next step would be to include bryophytes in the Acquisitions Policy so that ex situ collections could be developed to address this imbalance.

Cryptogams are a significant part of RBGE's research work, and this could be better reflected in the public display glasshouses. RBGE bryologist Neil Bell suggests that rare and spectacular bryophytes could be cultivated from wild-collected material, just as vascular plants are, as well as naturally occurring species being utilised. For example, Braithwaitea sulcata (Fig. 11) is a large, attractive and relatively rare species of epiphytic moss, occurring in New Zealand, Eastern Australia and New Caledonia (Neil Bell, pers. comm.). If bryophytes were included in the RBGE Acquisitions Policy, permits could be obtained for their collection on field trips and they could be subsequently cultivated within botanic garden displays.

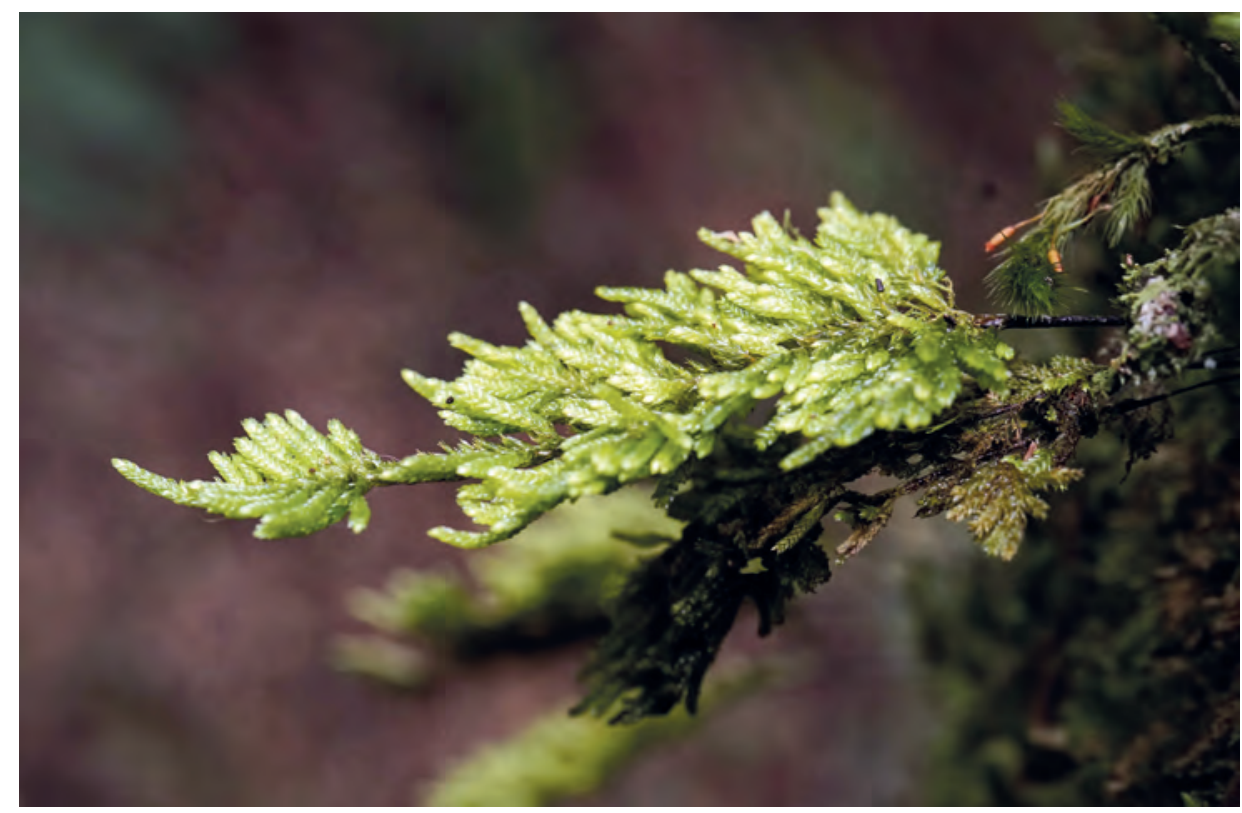

Fig. 11 Epiphytic moss Braithwaitea sulcata in New Zealand. Photo: ㄷ N. Bell. 
Botanic gardens have only been focusing on the conservation of biodiversity for a short part of their history, since the Convention on Biological Diversity came into force at the end of 1993 as a result of the 1992 Rio Earth Summit (Convention on Biological Diversity, 2005). Their role will become more and more crucial for biological conservation in the future, which requires an understanding of all areas of plant biodiversity. Continually developing living collections and botanical and horticultural knowledge is essential to provide the best possible resources for now and for research in the future. It is therefore essential that bryophytes are included in this conservation effort.

Studying and effectively managing the naturally occurring bryophyte diversity found in botanic gardens is a simple yet fascinating step in preparation for ex situ conservation of bryophytes in the future, expanding the range of diversity held within living collections.

\section{ACKNOWLEDGEMENTS}

Many thanks to RBGE horticultural staff Louise Galloway, Helen Yeats, Andrew Ensoll, Gunnar Øvstebø, David Tricker and Cameron Tasker for their help, knowledge and enthusiasm on this project. Thanks to Elizabeth Kungu for assistance with bryophtye identification and the loan of invaluable books. Many thanks to Nathan Phinney for moral support and help with editing.

Finally, many thanks to Neil Bell for the project suggestion, book loans, bryophyte identification, proof reading, use of photographs, and general help and enthusiasm.

\section{REFERENCES}

ATHERTON, I., BOSANQUET, S. \& LAWLEY, M. (2010). Mosses and Liverworts of Britain and Ireland. British Bryological Society, Plymouth.

CHEFFINGS, C., HARPER, M. \& JACKSON, A. (2004). Plant Diversity Challenge - The UK's Response to the Global Strategy for Plant Conservation. Available online: http://jncc.defra. gov.uk/pdf/PlantDiversityChallenge.pdf (accessed June 2018).

CONVENTION ON BIOLOGICAL DIVERSITY (2005). The Convention on Biological Diversiy: From Conception to Implementation. Secretariat of the Convention on Biological Diversity, Montreal.

CURTIS, E. (2006). The Story of Glasgow's Botanic Gardens. Argyll Publishing, Glendaruel.

DIXON, H. (1928). Hypopterygium atrotheca. The Journal of Botany British and Foreign, 66: 350-351. Available online: http://archive.bsbi.org.uk/Journal_of_Botany_1928.pdf (accessed May 2017).

ESSL, F., STEINBAUER, K., DULLINGER, S., MANG, T. \& MOSER, D. (2013). Telling a different story: A global assessment of bryophyte invasions. Biological Invasions, 15(9): 1933-1946. Available online: https://link.springer.com/content/ pdf/10.1007\%2Fs10530-013-0422-2.pdf (accessed May 2017). 
EVERT, R., RAVEN, P. \& EICHHORN, S. (2013). Raven Biology of Plants. W.H. Freeman, New York.

GLIME, J. (2008). Bryophyte Ecology. Michigan Technological University, Houghton, MI. Available online: www.bryoecol.mtu.edu/chapters_VOL5/7-2 JapaneseMossGardens.pdf (accessed May 2017).

GOFFINET, B. \& SHAW, A. (2009). Bryophyte Biology. Cambridge University Press, Cambridge.

IWATSUKI, Z. \& KODAMA, T. (1961). Mosses in Japanese gardens. Economic Botany, 15(3): 264-269.

KRUIJER, J. (2002). Hypopterygiaceae of the World. Blumea. Supplement, 13(1). Available online: www.repository.naturalis.nl/record/526321 (accessed November 2016).

LAUSEN-HIGGINS, J. (2009). Bryophyte diversity of structures in heritage gardens compared with adjacent naturally occurring rocks. Unpublished BSc thesis, RBGE, Edinburgh.

MARTIN, A. (2015). The Magical World of Moss Gardening. Timber Press, Portland, OR.

MOUNCE, R., SMITH, P. \& BROCKINGTON, S. (2017). Ex situ conservation of plant diversity in the world's botanic gardens. Nature Plants, 3(10): 795-802.

RAE, D., BAXTER, P., KNOTT, D., MITCHELL, D., PATERSON, D. \& UNWIN, B. (2006). Collection Policy for the Living Collection. RBGE, Edinburgh.

RUMSEY, F. (2001). Achrophyllum dentatum (hook. F. \& Wils.) Vitt \& Crosby (Hookeriaceae) naturalized in Britain. Journal of Bryology, 23(4): 341-344.

SIMPSON, M. (2010). Plant Systematics. Academic Press, Burlington, MA.

STARK, L., GREENWOOD, J. \& BRINDA, J. (2016). Desiccated Syntrichia ruralis shoots regenerate after 20 years in the herbarium. Journal of Bryology, 39(1): 85-93.

STECH, M. \& PFEIFFER, T. (2006). Molecular identity of Hypopterygium populations (Hypopterygiaceae: Bryopsida) from three European botanical gardens. Journal of Bryology, 28(2): 83-87.

STEVENSON, C. \& JONES, E. (1989). Vesicularia reticulata, a tropical moss established in British glasshouses. Journal of Bryology, 15(3): 624-626. Available online: www. tandfonline.com/doi/pdf/10.1179/jbr.1989.15.3.624 (accessed May 2017).

VANDERPOORTEN, A. \& GOFFINET, B. (2009). Introduction to Bryophytes. Cambridge University Press, Cambridge.

VILLARREAL, J., FORREST, L., COOPER, E. \& LONG, D. (2014). Phylogenetic affinities and conservation status of Telaranea murphyae Paton in Britain. Journal of Bryology, 36(3): 191-199. Available online: www.tandfonline.com/doi/full/10.1179/174328201 4Y.0000000106 (accessed May 2017).

WALTER, K.S. \& O’NEAL, M.J. (1985-2018). BG-BASE (Collection Management Software). BG-BASE Inc. \& BG-BASE (UK) Ltd. Available online: www.bg-base.com (accessed December 2017).

WATLING, R. (2007). Cryptogams in a horticultural setting in Scotland. Sibbaldia, 5: 109-114. 
APPENDIX I: SURVEY RESULTS

\begin{tabular}{|c|c|c|c|c|c|c|}
\hline Species & $\begin{array}{l}\text { Moss or } \\
\text { liverwort }\end{array}$ & $\begin{array}{l}\text { Relative } \\
\text { size }\end{array}$ & Abundance & $\begin{array}{l}\text { Primary } \\
\text { substrate }\end{array}$ & $\begin{array}{l}\text { Native } \\
\text { or } \\
\text { exotic }\end{array}$ & $\begin{array}{c}\text { Recorded } \\
\text { outside } \\
\text { at RBGE }\end{array}$ \\
\hline $\begin{array}{l}\text { Achrophyllum } \\
\text { dentatum }\end{array}$ & Moss & Medium & Very infrequent & Rock & Exotic & No \\
\hline $\begin{array}{l}\text { Amblystegium } \\
\text { serpens }\end{array}$ & Moss & Small & Frequent & Rock & Native & Yes \\
\hline $\begin{array}{l}\text { Atrichum } \\
\text { undulatum }\end{array}$ & Moss & Large & Very infrequent & Ground & Native & Yes \\
\hline $\begin{array}{l}\text { Brachythecium } \\
\text { rutabulum }\end{array}$ & Moss & Large & Infrequent & $\begin{array}{l}\text { Fossilised } \\
\text { stumps }\end{array}$ & Native & Yes \\
\hline $\begin{array}{l}\text { Conocephalum } \\
\text { conicum }\end{array}$ & Liverwort & Large & Highly abundant & All & Native & No \\
\hline $\begin{array}{l}\text { Dicranum } \\
\text { scoparium }\end{array}$ & Moss & Medium & Very infrequent & Wood, cork & Native & No \\
\hline $\begin{array}{l}\text { Didymodon } \\
\text { fallax }\end{array}$ & Moss & Small & Fairy abundant & Rock & Native & No \\
\hline Fissidens sp. & Moss & Small & Highly abundant & Rock & Exotic? & No \\
\hline $\begin{array}{l}\text { Fissidens } \\
\text { taxifolius }\end{array}$ & Moss & Medium & Infrequent & Rock & Native & No \\
\hline $\begin{array}{l}\text { Gyroweisia } \\
\text { tenuis }\end{array}$ & Moss & Very small & Infrequent & Rock & Native & No \\
\hline $\begin{array}{l}\text { Hypnum } \\
\text { resupinatum }\end{array}$ & Moss & Medium & Infrequent & Rock & Native & No \\
\hline $\begin{array}{l}\text { Hypopterygium } \\
\text { tamarisci }\end{array}$ & Moss & Large & Highly abundant & All & Exotic & No \\
\hline Lejeunea sp. & Liverwort & Very small & Very infrequent & Rock, leaf & Exotic? & No \\
\hline Lejeuneaceae 1 & Liverwort & Very small & Very infrequent & Rock & Exotic? & No \\
\hline Lejeuneaceae 2 & Liverwort & Very small & Very infrequent & Rock & Exotic? & No \\
\hline $\begin{array}{l}\text { Leptobryum } \\
\text { pyriforme }\end{array}$ & Moss & Small & Very infrequent & Rock & Native & Yes \\
\hline $\begin{array}{l}\text { Lophocolea } \\
\text { bidentata }\end{array}$ & Liverwort & Small & Abundant & All & Native & Yes \\
\hline Mnium hornum & Moss & Large & Very infrequent & Fern crown & Native & Yes \\
\hline $\begin{array}{l}\text { Oxyrrhynchium } \\
\text { hians }\end{array}$ & Moss & Medium & Highly abundant & Rock & Native & Yes \\
\hline Pellia endivifolia & Liverwort & Large & Highly abundant & $\begin{array}{l}\text { Rock, } \\
\text { ground }\end{array}$ & Native & Yes \\
\hline Plagiochilla sp. & Liverwort & Medium & Very infrequent & $\begin{array}{l}\text { Rock, } \\
\text { ground }\end{array}$ & Native? & No \\
\hline
\end{tabular}




\begin{tabular}{|c|c|c|c|c|c|c|}
\hline Species & $\begin{array}{l}\text { Moss or } \\
\text { liverwort }\end{array}$ & $\begin{array}{l}\text { Relative } \\
\text { size }\end{array}$ & Abundance & $\begin{array}{l}\text { Primary } \\
\text { substrate }\end{array}$ & $\begin{array}{l}\text { Native } \\
\text { or } \\
\text { exotic }\end{array}$ & $\begin{array}{c}\text { Recorded } \\
\text { outside } \\
\text { at RBGE }\end{array}$ \\
\hline $\begin{array}{l}\text { Plagiomnium } \\
\text { rostratum }\end{array}$ & Moss & Medium & Frequent & $\begin{array}{l}\text { Fern } \\
\text { caudex/ } \\
\text { crown, } \\
\text { ground }\end{array}$ & Native & No \\
\hline $\begin{array}{l}\text { Plagiomnium } \\
\text { undulatum }\end{array}$ & Moss & Large & Highly abundant & $\begin{array}{l}\text { Fern } \\
\text { caudex, } \\
\text { ground }\end{array}$ & Native & Yes \\
\hline $\begin{array}{l}\text { Rhizomnium } \\
\text { punctatum }\end{array}$ & Moss & Large & $\begin{array}{l}\text { Locally } \\
\text { abundant }\end{array}$ & Fern caudex & Native & No \\
\hline $\begin{array}{l}\text { Rhynchostegium } \\
\text { confertum }\end{array}$ & Moss & Small & Infrequent & Fern caudex & Native & Yes \\
\hline $\begin{array}{l}\text { Rhynchostegium } \\
\text { murale }\end{array}$ & Moss & Small & Frequent & Rock & Native & No \\
\hline $\begin{array}{l}\text { Thuidium } \\
\text { tamariscinum }\end{array}$ & Moss & Large & Very infrequent & Ground & Native & Yes \\
\hline Tortula muralis & Moss & Small & Very infrequent & Rock & Native & Yes \\
\hline $\begin{array}{l}\text { Tricholepidozia } \\
\text { tetradactyla }\end{array}$ & Liverwort & Small & $\begin{array}{l}\text { Locally } \\
\text { abundant }\end{array}$ & Rock & Exotic & No \\
\hline $\begin{array}{l}\text { Vesicularia } \\
\text { reticulata }\end{array}$ & Moss & Large & $\begin{array}{l}\text { Locally } \\
\text { abundant }\end{array}$ & $\begin{array}{l}\text { Rock/ } \\
\text { sediment in } \\
\text { stream \& } \\
\text { pond }\end{array}$ & Exotic & No \\
\hline
\end{tabular}

\section{APPENDIX II: RESULTS: SUMMARY OF INTERVIEWS WITH} HORTICULTURAL STAFF

\section{Fern House}

Helen Yeats is responsible for the maintenance of the Fern House. Thalloid liverwort, Conocephalum conicum, is the only problematic species that requires weeding and the public often enquire about it due to its abundance and visual impact within the display. She expressed interest in having a workshop on bryophytes and suggested that a handout and species list would be useful for horticultural staff. She is keen to have black labels made up for large, easily defined populations of bryophytes, with 'Moss' or 'Liverwort' included for clarity.

Louise Galloway is a Glasshouse Supervisor and Andrew Ensoll is a Senior Horticulturist responsible for the fern research collections. They agreed that Conocephalum conicum is a major weed in the Fern House as it smothers fern crowns, stunting the development of new croziers and outcompeting filmy ferns. They would be interested in having bryophytes incorporated into the collection if they were showy and added visitor interest, for example Dawsonia superba from New Guinea which grows to $60 \mathrm{~cm}$ in height. Ensoll suggested it may be difficult to bring back wild-collected 
bryophytes as soil cannot be brought back and they are unlikely to survive quarantine. Galloway and Ensoll agreed that it would be appropriate to install black plastic labels on persistent populations of bryophytes such as large patches of C. conicum and Hypopterygium tamarisci, and common names could be included to make them more accessible to the public.

\section{Arid Lands}

Gunnar $\emptyset$ vsteb $\emptyset$ is responsible for the dry habitat collections, which currently contain the only wild-collected bryophytes in the RBGE Living Collection. The oldest of these accessions is thalloid liverwort, Plagiochasma rupestre, collected in 2011 in the Chihuahua desert, west Texas. As part of a field trip to collect xerophytic ferns, it was found in shady crevices alongside fern species such as Notholaena standlyi and Astrolepis sinuata. The Arid Lands display now includes several collections of Plagiochasma spp., thalloid liverwort Riccia sp. and an unidentified Saudi Arabian moss. Although perhaps initially surprising that the only deliberately cultivated bryophytes at RBGE are in the Arid Lands collection, Øvsteb $\varnothing$ makes a case for them as an interesting and logical addition, as many lithophytic species of moss and liverworts are better adapted to survive drought and desiccation than desert-dwelling angiosperms.

\section{Carnivorous plant display}

David Tricker is responsible for the carnivorous plant case, where mosses are an important element. This display was replanted three years ago, using mosses occurring in the Montane Tropics Glasshouse. Moss provides a suitable growing substrate for epiphytic carnivorous plants because it assists in maintaining high humidity levels and also requires these to thrive; it can therefore be used as an indicator that watering is required. Sphagnum sp. and Polytrichum commune can be invasive within a growing case, smothering small plants. Tricker would be interested in using moss species that occur as part of natural carnivorous plant communities. However, the artificial peat and bark compost used in the growing case create artificial conditions, where mosses may grow much more vigorously than they would on the sandier soils on which natural carnivorous plant communities occur in southern North America.

The carnivorous case is the only location at RBGE where the rare hornwort Anthoceros punctatus occurs naturally. This is an accessioned population and so it needs to be maintained, thriving on frequently disturbed bare soil. 
